\title{
Plum leaf scald: characteristics of the causative agent, symptoms, dissemination, control and prevention
}

\author{
Gislaine Gabardo ${ }^{1}$, Clandio Medeiros da Silva², Henrique Luis da Silva ${ }^{3}$
}

Abstract - The very slow-growing gram-negative bacterium, Xylella fastidiosa, inhabits the xylem and is vector-borne. It causes several diseases in plants, including plum leaf scald (PLS), which is the main limiting factor over the years for the crop expansion, both in productivity and in cultivation areas in Brazil. There is little information about the management and control of the disease. Brazilian breeding programs of plum trees have launched few resistant cultivars. The aim of this work was to carry out a systematic review with current information regarding PLS, characteristics of the causative agent, symptoms, transmission/dissemination, control and prevention. The use of certified propagation material, free from bacteria and the elimination of infected plants are the main measures used in Brazil. The vast majority of commercial cultivars are highly susceptible to bacteria and only few cultivars of interest have any resistance. In 2017 the Agricultural Research and Rural Extension Company of Santa Catarina launched the 'Zafira' plum cultivar, the first cultivar for commercial purposes that is not naturally infected; however, it was observed that the transmission of the bacteria occurs by grafting. The Institute of Rural Development of Paraná IAPAR-EMATER evaluated different plum crosses and concluded that the 'PR-1095' genotype was the most resistant and did not show any foliar symptoms of the disease. However, the PCR test revealed the presence of the bacteria, indicating that the genotype is probably tolerant. In contrast, 'PR 1142', 'PR 1149' and 'PR 1260' genotypes do not show symptoms or the presence of the bacteria by PCR, resulting in resistance to the disease. These genotypes have not been released, and further studies are still needed.

Index terms: Xylella fastidiosa subsp. multiplex, Prunus salicina Lindl., productivity.

\section{Escaldadura das folhas da ameixa: características do agente causal, sintomas, disseminação, controle e prevenção}

Corresponding author: gislainegabardo2007@yahoo. com.br

Received: February 20, 2021 Accepted: June 07, 2021

Copyright: All the contents of this journal, except where otherwise noted, is licensed under a Creative Commons Attribution License.

\section{$($ (cc) $\mathbf{E Y}$}

Resumo -A bactéria Gram-negativa, e de crescimento muito lento, Xylella fastidiosa, habita o xilema e é transmitida por vetores. Causa várias doenças em plantas, dentre as quais a escaldadura das folhas da ameixeira (EFA).É o principal fator limitante ao longo dos anos para a expansão da cultura, tanto em produtividade quanto em áreas de cultivo no Brasil. Há poucas informações sobre o gerenciamento e o controle da doença. Os programas brasileiros de melhoramento genético da ameixeira têm lançado poucas cultivares com resistência. O objetivo do trabalho foi realizar a revisão sistematizada, com informações atuais referentes à EFA, características do agente causal, sintomas, transmissão/disseminação, controle e prevenção. O uso de material de propagação certificado, livre de bactérias, e a eliminação de plantas infectadas são as principais medidas utilizadas no Brasil. A grande maioria das cultivares comerciais é altamente suscetível às bactérias, e apenas algumas cultivares de interesse têm alguma resistência. Em 2017, a Empresa de Pesquisa Agropecuária e Extensão Rural de Santa Catarina lançou a cultivar de ameixa Zafira, primeira cultivar para fins comerciais que não é naturalmente infectada; porém, foi observado que a transmissão da bactéria ocorre por enxertia. O Instituto de Desenvolvimento Rural do Paraná IAPAR-EMATER, avaliando diferentes cruzamentos de ameixeira, concluiu que o genótipo PR1095 foi o mais resistente e não apresentou nenhum sintoma foliar da doença. No entanto, o teste de PCR acusou a presença da bactéria, indicando, que o genótipo, provavelmente, é tolerante. Em contraste, os genótipos PR 1142, PR 1149 e PR 1260 não apresentam sintomas a campo nem a presença da bactéria por PCR, ocorrendo resistência à doença. Estes genótipos não foram lançados, sendo necessário ainda novas pesquisas.

Termos para indexação: Xylella fastidiosa subsp. multiplex, Prunus salicina Lindl., produtividade.

${ }^{1}$ Ph.D. in Phytopathology, Ponta Grossa State University (UEPG), Ponta Grossa, Paraná, Brazil. E-mail: gislainegabardo2007@yahoo.com.br (ORCID 0000-0003-0723-6297)

${ }^{2} \mathrm{Ph} . D$. in Plant Breeding, Institute of Rural Development of Paraná IAPAR-EMATER (IDR-Paraná), Ponta Grossa, Paraná, Brazil. E-mail: clandio@idr.pr.gov.br (ORCID 0000-0002-0569-4836)

${ }^{3}$ Master's in Phytotechnics, Institute of Rural Development of Paraná IAPAR-EMATER (IDR-Paraná), Ponta Grossa, Paraná, Brazil. E-mail: hluis@idr.pr.gov.br ${ }^{\text {(ORCID 0000-0002-0078-1666) }}$ 


\section{Introduction}

Plum cultivation (Prunus salicina Lindl.) has significant economic importance in Brazil, especially in the southern states of the country due to favorable climatic conditions for the crop development. In 2017, the area cultivated with plum trees in the country was 4,200 hectares, with annual production of approximately 40 thousand tons (EMBRAPA, 2017). The main fruit producing states are Rio Grande do Sul, Santa Catarina and Paraná. Paraná has area of 648.0 hectares, harvesting 10.3 thousand tons of fruits (SEAB/DERAL, 2017).

In Brazil, the production of plum fruits is mainly directed for fresh consumption. National production is not enough to meet the demand of the domestic market, meeting approximately $30 \%$ of the total annual volume consumed in the country, being necessary to import the product from neighboring countries such as Argentina and Chile. Plum ranks $3^{\text {rd }}$ in Brazilian imports of temperate climate fruits, mainly from Argentina (47.3\%), Spain (25.0\%) and Chile (21.3\%) (FAO, 2018).

This characterizes a deficit market, indicating good potential for the crop expansion in Brazil (EIDAM, PAVANELLO, AYUB, 2012); however, the main limiting factor over the years for the crop expansion, both in productivity and in cultivation areas in the country, is the Plum Leaf Scald (PLS), a disease caused by gramnegative bacterium Xylella fastidiosa subsp. multiplex Wells (SCHNEIDER; DE AZEVEDO FILHO, 2014).

The disease is widely disseminated in the main producing regions of Brazil (PALACIO BIELSA, 2017; GABARDO et al., 2020). The phytosanitary problem caused by PLS drastically affects the productivity and longevity of plum plants, which increases production cost and reduces competitiveness in relation to imported fruits (CASTRO, 2010).

PLS may make the economic plum exploitation in Brazil unfeasible. It has been the main factor for the crop decline in the southern and southeastern states of the country (MAY DE MIO; GARRIDO; UENO, 2004; MÜLLER et al., 2021), in addition to causing the early abandonment of orchards. There is little information about the management and control of the disease. In this context, the aim of this work was to gather information regarding the characteristics of the pathogen, symptoms, transmission/dissemination, control and prevention, thus collaborating to develop strategies to control and reduce the spread of this disease in Brazil.

\section{Causative agent characteristics}

X. fastidiosa (Xanthomonadales: Xanthomonadaceae) is a strictly aerobic gram-negative bacilliform bacterium, with no motility or flagella. $X$. fastidiosa strains are currently categorized into five subspecies: fastidiosa, pauca, multiplex, sandyi and morus, which are presumed to have originated in Central America (subsp. fastidiosa), South America (subsp. pauca) and North America (subsp. pauca), multiplex, sandyi and morus (ALMEIDA; NUNNEY 2015; SICARD et al. 2018).

The causative PLS subspecies is $X$. fastidiosa subsp. multiplex. Its size is variable, measuring from 0.25 to $0.35 \mu \mathrm{m}$ in diameter and 0.9 to $3.5 \mu \mathrm{m}$ in length. Its main characteristic is the slow growth in culture medium with suitable temperatures between 26 and $28^{\circ} \mathrm{C}$ and optimum pH between 6.5 and 6.9 (WELLS et al., 1987; SADDLER, BRADBURY, 2015). It has Type IV pili, responsible for the upward vertical plant movement, and Type I and II pili, responsible for biofilm formation and cell aggregation (LI et al., 2007; RETCHLESS et al., 2014).

Other pathogenic factors that promote bacterial virulence include the production of cell wall degrading enzymes such as glucanases, xylanases and polygalacturonases, in addition to polygalacturonase (pglA), which is known to contribute to the degradation of membranes that separate xylem vessels, consequently helping in the systemic colonization of the plant by bacteria (ROPER et al., 2017).

Bacteria are limited to the xylem, obstructing vessels and blocking part of the plant's vascular system responsible for the translocation of water and nutrients. Due to the occlusion of xylem vessels, host resistance reaction occurs such as deposition of gum, pectin, formation of tyloses and calcium crystals, resulting in water stress and possible destruction of punctuation membranes, causing cavitation in vessels with embolism (WELLS et al., 1987; ALVES, 2003).

$X$. fastidiosa subsp. multiplex occurs in various plants, including cultivated, ornamental and wild trees (SCHAAD et al., 2004). In some plant species, it is considered the causative agent of diseases, but not in others, being considered as hosts of bacteria for at least 28 families of mono and dicotyledons (AZEVEDO FILHO et al., 2011). The occurrence of $X$. fastidiosa subsp. multiplex in ornamental plants in southern France and the interception of other $X$. fastidiosa subspecies and strains have become a major concern for the European community involved in plant protection (SAFADY et al., 2019). 
This bacterium parasitizes several plant species with economic interest, such as grapevine, peach, almond, plum, oak and orange. $X$. fastidiosa was cited in more than 360 plant species belonging to 75 botanical families (DG SANTE, 2017). The first disease associated with $X$. fastidiosa was in grapevines, known as Pierce's disease (ALVES, 2003). Several other diseases, in addition to PLS, are known and cause problems in crops around the world, among which Citrus Variegated Chlorosis (CVC) stands out (MILANEZ et al., 2017).

In addition to the already known diseases, studies have shown the presence of the bacterium in alternative hosts present in orchards, which act as reservoirs for the microorganism and possible sources of inoculum for the causative disease agent. Among these plants, Bidens pilosa (picão-preto), Parthenium hysterophorus (losna branca), Rumex sp. (língua-de-vaca) and Solanum americanum (pretinha) stand out, which occur abundantly in plum orchards and are proven X. fastidiosa hosts, being detected both in the shoots and roots of these weeds (LEITE et al., 1997).

The bacterium was also recently diagnosed in olive trees (Olea europaea L.), causing a devastating impact due to the outbreak known as Olive Quick Decline, which has already killed millions of olive trees in Italy, Spain and Greece (GODEFOID et al., 2020). In addition to Europe, $X$. fastidiosa subsp. multiplex was also detected in olive trees grown in California, USA (O'LEARY et al., 2020).
Olive cultivation is typically Mediterranean; however, it has recently been introduced in southern Brazil, with great potential for expansion, and the presence of the bacterium causes great concern (COLETTA FILHO et al., 2016; SAFADY et al., 2019). In Brazil, the disease is monitored by researchers from the Agronomic Institute of Campinas (IAC), belonging to the Secretariat of Agriculture and Supply of the State of São Paulo.

The detection of $X$. fastidiosa subsp. multiplex at molecular level is difficult due to the low concentrations of bacteria in insects and asymptomatic plant tissue, and non-uniform distribution in infected plants (FRANCIS et al., 2006). Laboratory PCR (Polymerase Chain Reaction) tests have been used, complementing the observation of field symptoms (HARPER et al., 2010; GABARDO et al., 2020).

\section{Symptoms}

Symptoms are usually associated with water stress. The leaves of infected plants initially show slight chlorosis at the edges, which progresses to necrosis. Necrotic areas advance towards the interior of the leaf blade and present gray or dark brown color, showing the typical symptoms of scald burning, as if they had been scalded, thus giving rise to the name of the disease (Figure 1).
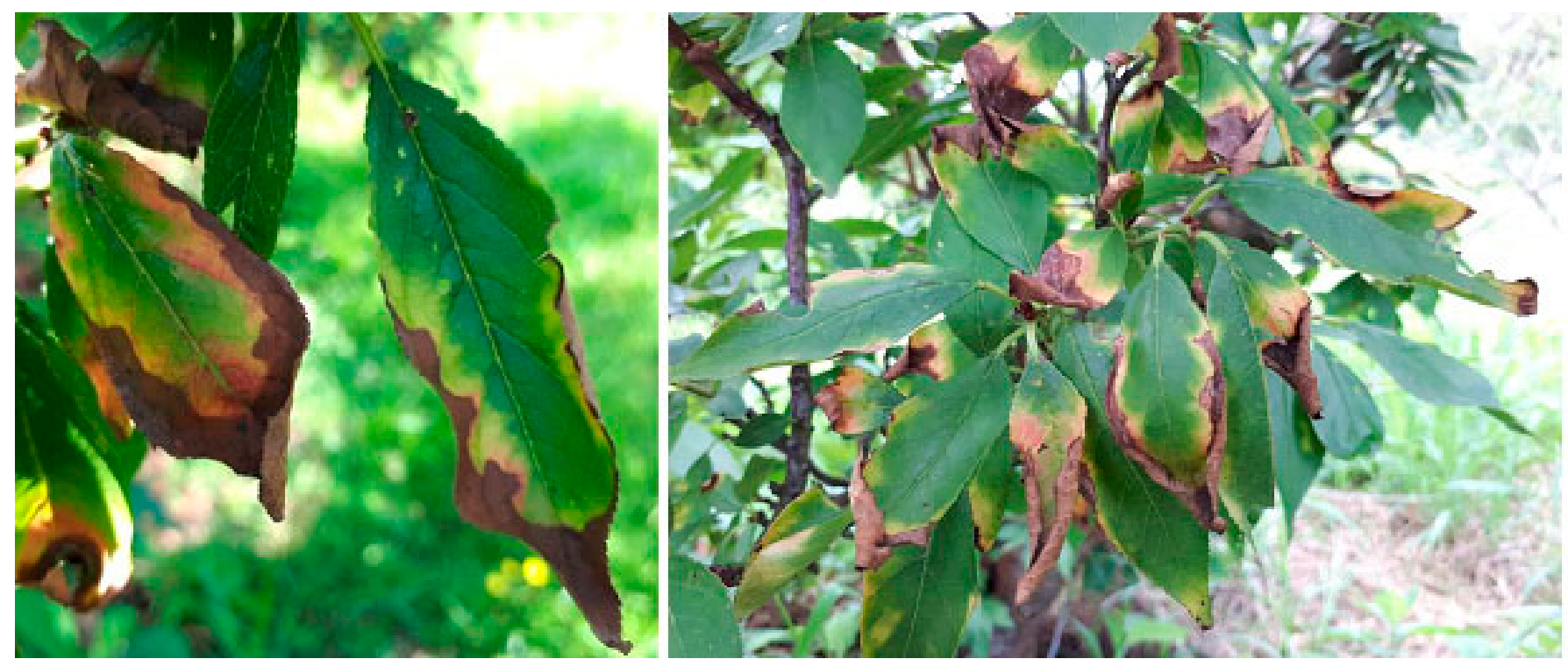

Figure 1. Symptoms of plum scald on leaves and branches (leaves showing holonecrotic symptoms, with chlorosis of the leaf blade followed by subsequent necrosis in the edges of adult leaves). Ponta Grossa, PR, 2020. Source: Gislaine Gabardo. 
Symptoms on leaves are more visible in the months of January and February due to the plant's greater water demand (SCHNEIDER; AZEVEDO, 2014), as there is a dysfunction in the water conduction system related to occlusions of xylem vessels by "gums", tyloses or bacterial cells (ALVES, 2003). After burning the edges of adult leaves, leaves wrinkle and fall off the trees. As the disease progresses, attacked branches dry from the apex (Figure 2).
PLS is a localized disease. Symptomatic and healthy branches are usually observed in the same plant (Figure 2), as well as diseased and asymptomatic plants in the same location in the orchard (Figure 3) (SCHNEIDER; AZEVEDO, 2014). This is a random disease regarding both the spread of symptoms in branches and the occurrence of the disease in certain plants in the same area (PURCELL, 1979).

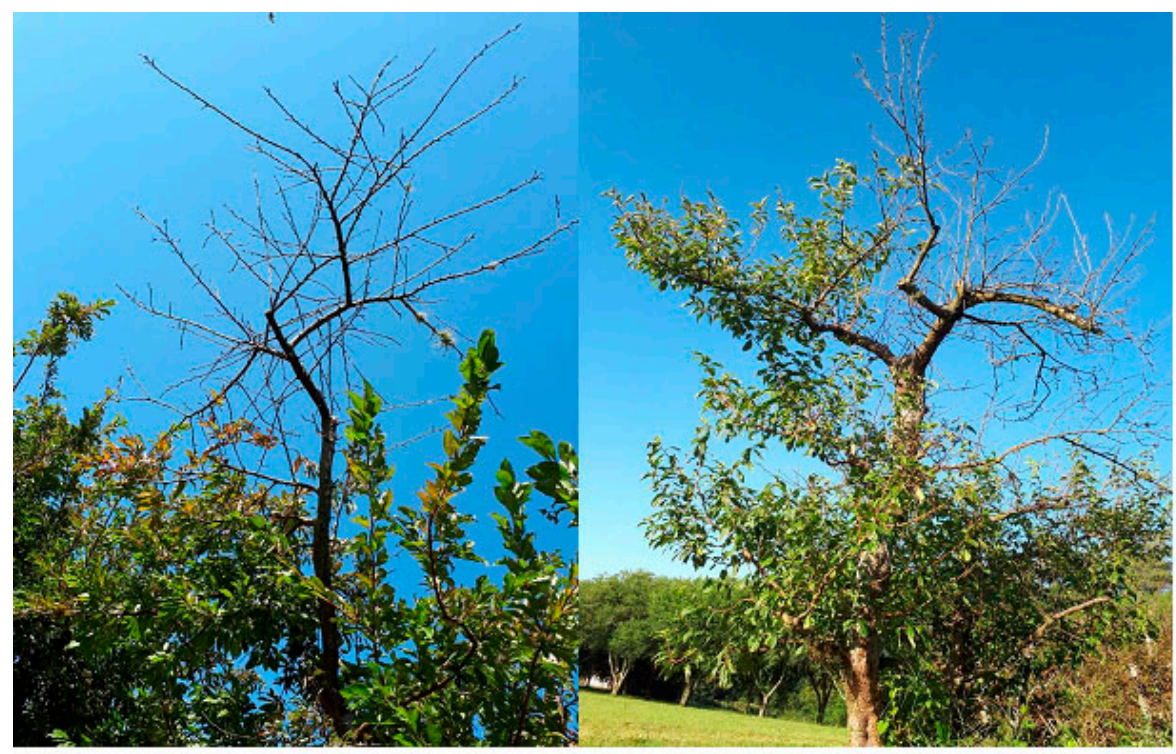

Figure 2. Plum scald symptoms in partially and/or totally infected branches, showing apical dryness due to leaf scald. Ponta Grossa, PR, 2020. Source: Gislaine Gabardo.

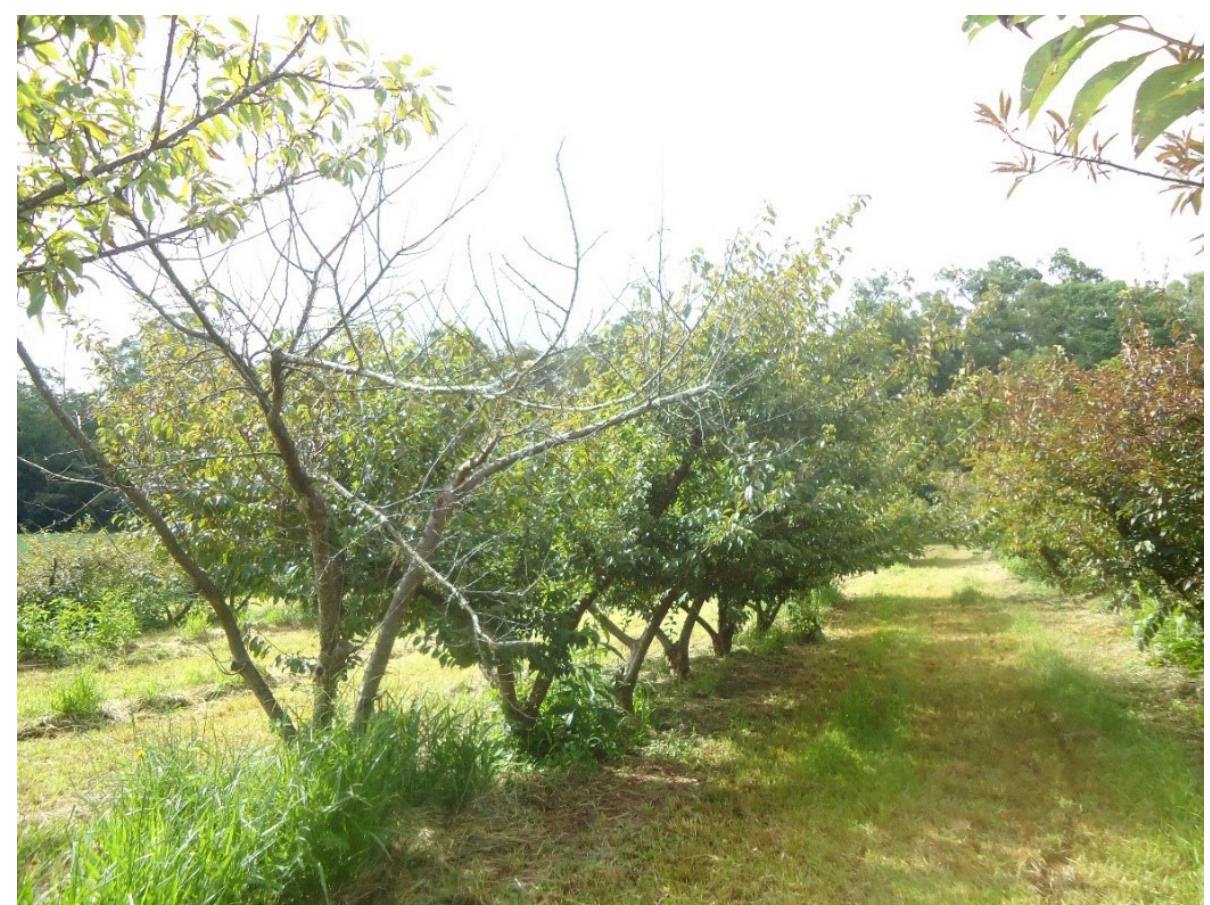

Figure 3. Plum plants affected by leaf scald and asymptomatic in the same location. Ponta Grossa, PR, 2020. Source: Gislaine Gabardo. 
As a consequence of the disease, there is reduction in vigor, productivity and fruit size. Fruits that form on affected branches are of small size. The bacterium spreads in the host and, depending on the susceptibility of the cultivar, the entire plant dries up (Figure 4) (MAY DE MIO; GARRIDO; UENO, 2004).

Other factors, such as water stress, excessive fruit production, damage caused by agricultural machinery in roots and in the plant's own senescence, increase the disease severity (HOPKINS; PURCELL, 2002). The disease also causes great stress to plants, weakening it and predisposing it to attack by insects and fungi (CASTRO, 2010).
The plum plant can be compromised by the disease from the moment grafting takes place or even when planting new seedlings, since symptoms usually take two to three years to manifest, as it is necessary that the bacterial population grow and spread (CASTRO, 2010).

Through observations performed by researchers and producers, it is known that, generally, after the appearance of the first symptoms, it takes three to five years for the orchard to become unproductive (DUCROQUET et al., 2001). The decline in vigor and production from $80 \%$ to $90 \%$ culminates in the death of plants, drastically reducing the period of economic productivity, since the lifetime of plum orchards is around 14 years (MADAIL, 2007), with orchard abandonment and destination of the area for other agricultural activities (Figure 4).

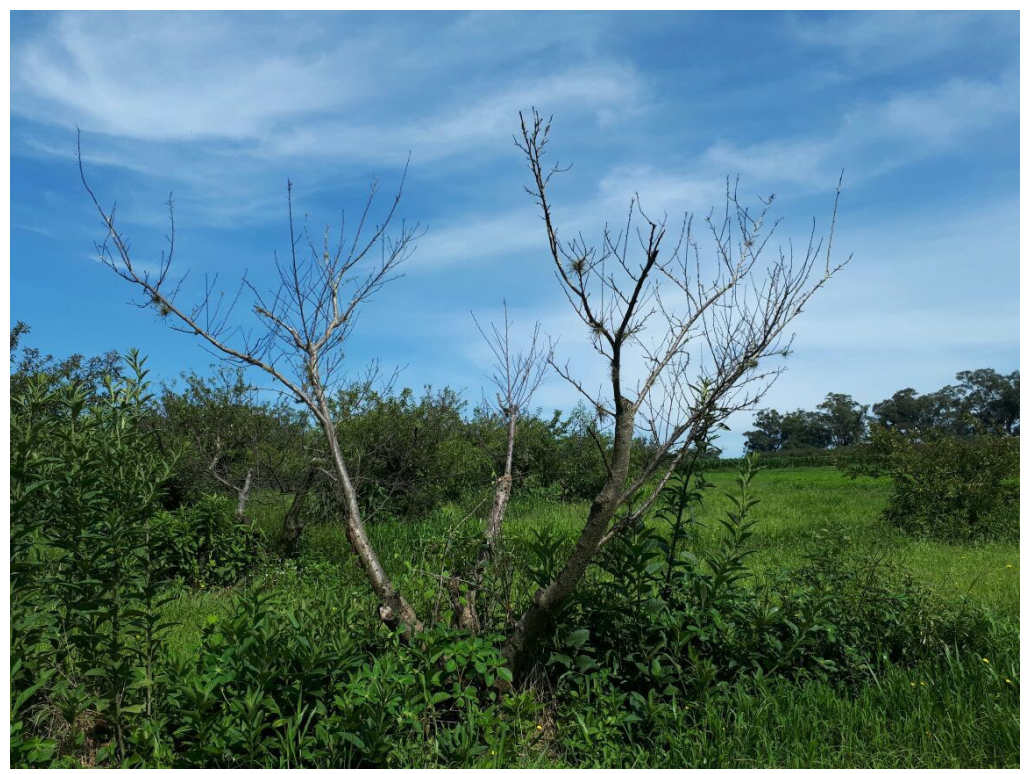

Figure 4. Dead plum plant, causing the orchard abandonment due to plum leaf scald. Ponta Grossa, PR, 2020. Source: Gislaine Gabardo.

\section{Transmission / dissemination}

The phytopathogen is transmitted by leafhoppers (Hemiptera: Cicadellidae, Cicadellinae) (Figure 5), which feed on the xylem of contaminated plants (REDAK et al., 2004). The bacterium adheres and multiplies in the anterior part of the oral system (stomodeum), which presents physical, morphological and nutritional characteristics similar to those of xylem vessels (PURCELL, 1979; JANSE; OBRADOVIC, 2010).
Among leafhopper species transmitting the disease commonly found in orchards in southern and southeastern Brazil, Macugonalia cavifrons (Stål), Macugonalia leucomelas (Walker) and Sibovia sagata (Signoret) stand out (MÜLLER et al., 2021). 


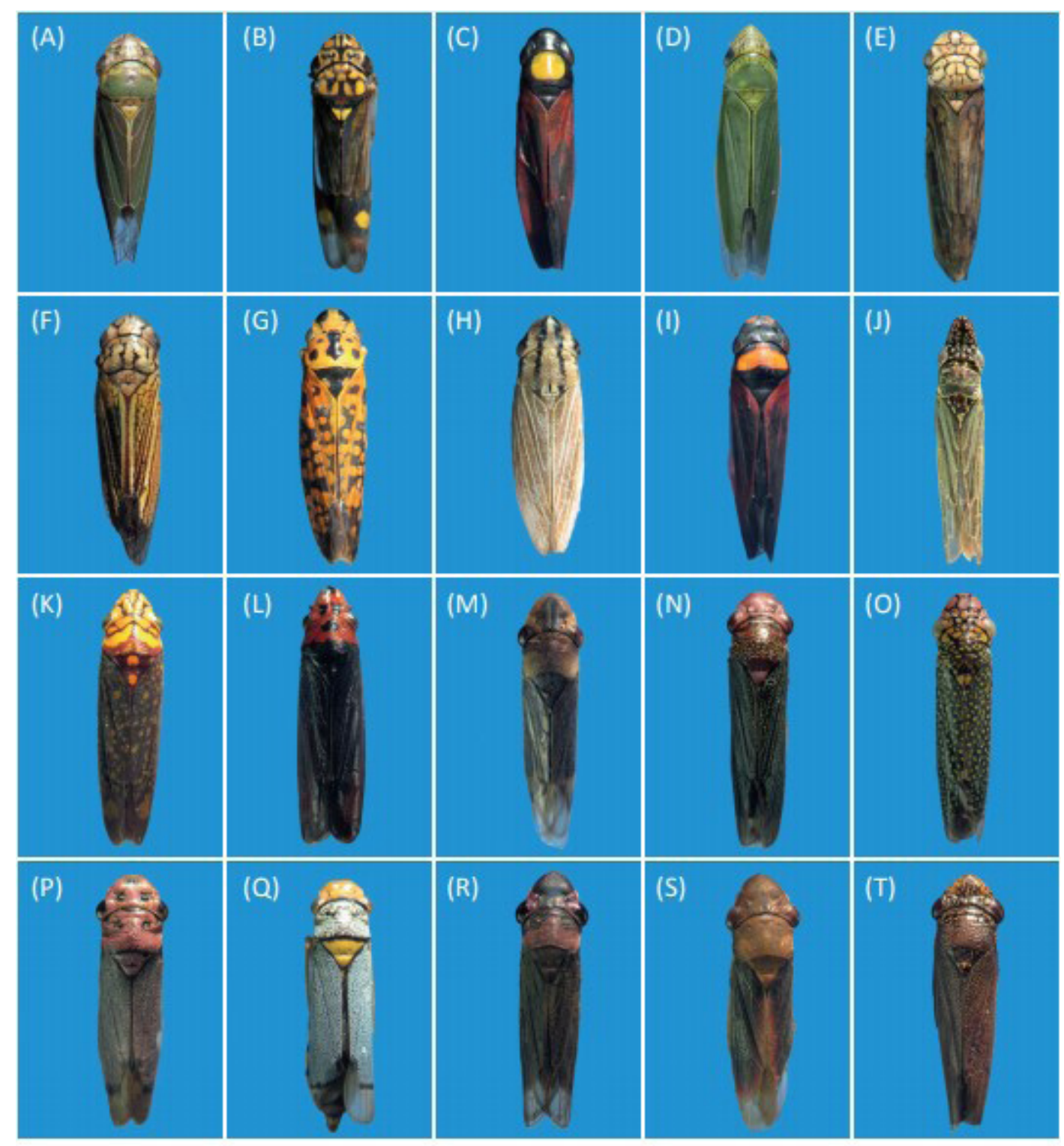

Figure 5. Leafhoppers (Cicadellidae: Cicadellinae) associated with plum crops in southern Brazil: Cicadellini: A. Bucephalogonia xanthophis (Berg, 1879); B. Dilobopterus dispar (Germar, 1821); C. Erythrogonia dorsalis (Signoret, 1853); D. Hortensia similis (Walker, 1851); E. Macugonalia geographica (Signoret, 1855); F. Parathona gratiosa (Blanchard, 1840); G. Pawiloma victima (Germar, 1821); H. Sonesimia grossa (Signoret, 1854); I. Spinagonalia rubrovittata Cavichioli, 2008. Proconiini: J. Acrogonia citrina (Marucci \& Cavichioli, 2002); K. Aulacizes conspersa (Walker, 1851); L. Aulacizes quadripunctata (Germar, 1821); M. Homalodisca ignorata (Melichar, 1924); N. Molomea consolida (Schröder, 1959); O. Molomea lineiceps (Young, 1968); P. Molomea personata (Signoret, 1854); Q. Molomea xanthocephala (Germar, 1821); R. Oncometopia facialis (Signoret, 1854); S. Oncometopia fusca (Melichar, 1925); T. Tapajosa rubromarginata (Signoret, 1855). Source: adapted from Wilson S. de Azevedo Filho and Graziela Poletto. 
PLS dissemination also occurs through propagation material, such as grafting carried out from infected material and contaminated seedlings (DUCROQUET et al., 2001; AZEVEDO FILHO et al., 2011). Insects act in the local PLS dissemination, while other forms of propagation (contaminated seedlings) contribute to PLS dissemination over long distances. Thus, the control of vector insects alone is probably not enough to reduce the expansion of PLS at an economically and ecologically viable cost (DUCROQUET et al., 2001; MIRANDA et al., 2008).

Leafhoppers have a specialized oral apparatus, allowing penetration into plant tissues, which favors the inoculation of pathogens that escape the natural barriers of the epidermis (HARRIS; MARAMOROSCH, 2013). These insects are organisms that are characterized by having powerful head musculature that allows them sucking the xylem at high levels of negative tension, so bacteria can be transported from xylem vessels to the oral system, finding adequate environment for multiplication (REDAK et al., 2004).

Transmission occurs in the following order: a) acquisition of bacteria from the source plant (infected), b) anchorage, retention and multiplication of bacteria in the vector cuticle (cibarium), and c) displacement and inoculation into a new host (CHATTERJEE et al., 2008) (Figure 6).

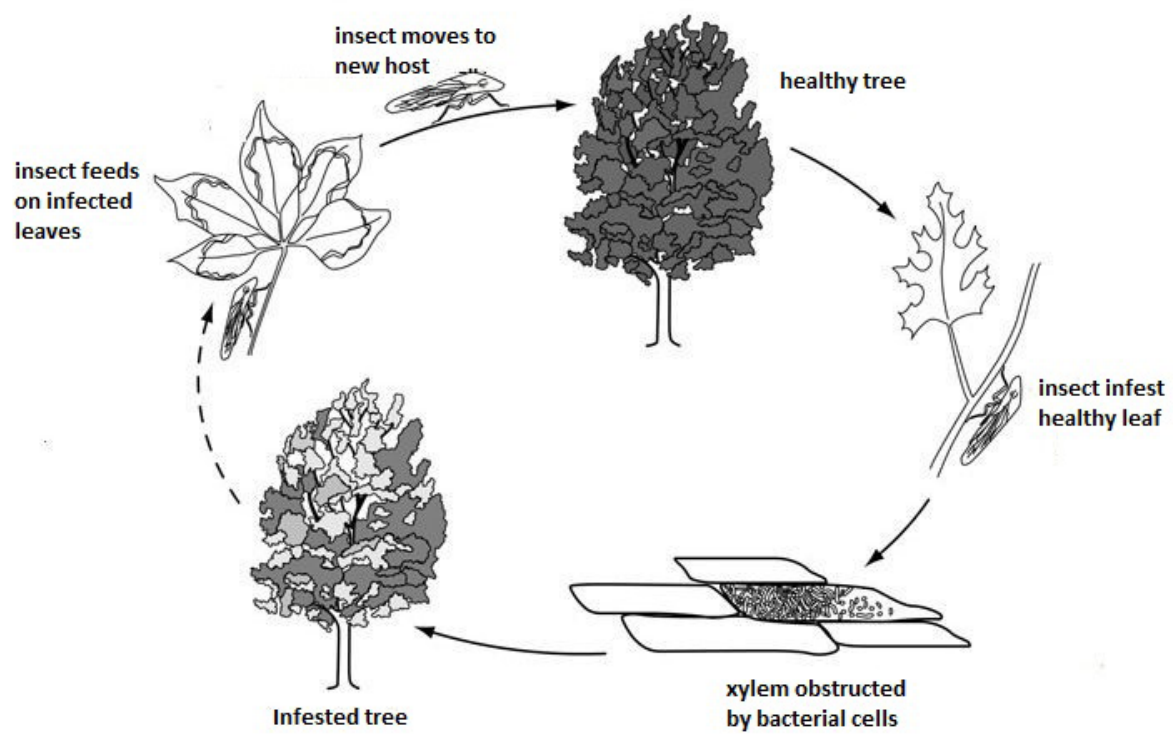

Figure 6. Xylella fastidiosa life cycle - Adapted from Gould \& Lahomb, 2007.

Aspects related to the insect-plant interaction can also influence the transmission efficiency. The leafhopper species, the feeding site on the plant, the ingestion rate and the soil water conditions can also influence the survival and feeding of the leafhopper on the host plant (PEREIRA et al., 2005; MÜLLER et al., 2021). As the distribution of $X$. fastidiosa is uneven in the plant, the feeding site of the vector is one of the main factors that can influence the probability of acquisition or inoculation of the pathogen (MIRANDA et al., 2008).

Leafhoppers acquire the bacteria during feeding on infected plants. However, at the nymphal stage, they lose infectivity with ecdysis due to the stomodeum (cibarium), where the adhered bacterium is of ectodermal origin and is changed to give rise to a new cuticular layer (YONCE; SHANG, 1987). The loss of vector infectivity after the change and the lack of a latent period (time between pathogen acquisition and inoculation) confirm that the foregut is the site from which $X$. fastidiosa is transmitted (KILLINY; ALMEIDA, 2009).
On the other hand, leafhoppers that acquire the pathogen in adulthood can transmit it throughout their lives indefinitely, as the longer time after acquisition, the greater the bacterial populations within the insect due to pathogen multiplication (HILL; PULCELL, 1995). Although there is pathogen propagation in the vector body, there is no evidence of transovarian $X$. fastidiosa transmission to the progeny (FREITAG, 1951; JANSE \& OBRADOVIC, 2010).

The dissemination of the disease can also occur through grafting performed with the vegetative bud, removed from a mother plant contaminated with the scald bacteria, giving rise to an already diseased seedling, which does not always show symptoms in the nursery. Once planted in the field, this seedling will show the first symptoms after the first or second year (DALBÓ et al., 2016). 
The long incubation period characteristic of the disease and the fact that grafts from asymptomatic infected trees can transmit $X$. fastidiosa seem to be the main factors in the dissemination process. From then on, the natural dissemination mechanisms would act, in this case, by the action of vectors through a diffusion process that advances with variable speed according to climatic conditions, density and susceptibility of host plants and efficiency of vectors.

Regarding transmission through pruning shears, the fact could not be experimentally demonstrated (SCHNEIDER; AZEVEDO, 2014). Plant material such as wood, fruit and ornamental foliage present low risk of transmission. However, PLS is characterized as a disease of rapid spread both between and within orchards, and even more contagious than Citrus Variegated Chlorosis (CVC), due to the reduced size of plum orchards compared to citrus areas.

\section{Control and prevention measures}

Once $X$. fastidiosa has established itself in an area, its control is very difficult or impossible. There is no well-established chemical management recommended to control PLS. Therefore, all efforts should be directed towards preventing its introduction into new areas, highlighting the acquisition of healthy seedlings, field monitoring of diseased plants and vectors, eradication of plant material with symptoms, among others, in order to avoid the establishment of orchards close to infected areas and the planting of disease-resistant cultivars (DUCROQUET et al., 2001; MÜLLER et al., 2021).

In the field, leafhopper control should be the focus, since it alone can contaminate the healthy orchard. The chemical control of the vector is performed with contact or systemic insecticides applied by spraying, via soil or on the plant trunk, similarly to the CVC control. According to Yamamoto et al. (2000), the use of systemic insecticides applied via plant trunk is an efficient option and less aggressive to the environment. However, the application of insecticides is a strategy that must be used with caution, as it can cause undesirable side effects, such as biological imbalance and outbreak of secondary pests.

With regard to obtaining bacteria-free plum seedlings, propagation material must be used for the graft collected from bacterial-free mother plants (SANDERLIN; MELANSON, 2008; KRUGNER et al., 2016). After grafting, seedlings must develop with effective leafhopper control in the nursery and its surroundings, in addition to the nursery being far from contaminated orchards. The greatest efficiency to keep the seedling in its formation phase, free from contamination, is obtained by producing it protected under a shelter to prevent contamination, as requirement for the production of citrus seedlings (PALACIO BIELSA, 2017).
Diseased seedlings can carry the disease over long distances, across state and country borders, if they do not pass quarantine inspection. Thus, grafting buds and contaminated seedlings, unless new studies prove the contrary, would be the only ways of introducing the disease in new regions in the cultivation of scald-free plums (CATI, 2009).

The production of bacteria-free materials can be achieved with thermotherapy $\left(48^{\circ} \mathrm{C}\right.$, for 40 minutes). The planting of suspicious seedlings or those from affected regions should be avoided. Only certified plum seedlings with health certificate for PLS should be used (MAY DE MIO; GARRIDO; UENO, 2004).

Another relevant fact is that seeds are free from this type of bacteria, so the use of rootstocks multiplied by seeds is a good precaution in addition to strict vector control, which should be greater in orchards in the formation phase and in the spring and summer months, when there is greater flow of sprouts and leafhoppers, in addition to the use of cover crops using only grasses, as they are less favorable to the proliferation of vectors (DUCROQUET et al., 2001).

Periodic inspections in the orchard should be performed especially from January to March, when symptoms are easier to recognize. Plants or plant parts affected by the disease must be pruned $100 \mathrm{~cm}$ below the last leaf with symptoms, removed and burned to eliminate the outbreaks of the disease, thus preventing its dissemination (MAY DE MIO; GARRIDO; UENO, 2004).

The elimination of symptomatic plants or branches is a practice that may be viable in moderately resistant cultivars (e.g., 'Chatard' and 'Amarelinha'). However, for susceptible cultivars, the most planted, this practice is unfeasible, because when plants present the symptom, they are already quite debilitated and the bacterium has probably already been spread to other plants by vectors. Thus, according to Ducroquet et al. (2001), the elimination of plants or branches would not have the desired effect of interrupting the disease dissemination in susceptible cultivars.

It is important to emphasize that none of these measures, if adopted in isolation, is capable of significantly reducing the incidence of the disease because each one acts in a specific cultivation stage. Combined control measures must be adopted by producers.

In view of the difficulty in controlling the disease, the choice of cultivar becomes an important factor to be considered. The use of resistant cultivars is the method that least affects production costs, as long as there is available material. Breeding programs have been aimed at the development of new cultivars both in research agencies of Paraná (Institute of Rural Development of Paraná - IDR) and Santa Catarina (Agricultural Research and Rural Extension Company of Santa Catarina - EPAGRI). Dalbó et al. (2016) investigated sources of resistance to 
PLS and two forms of total resistance were identified. In one, resistance is complete, and in the other, only natural transmission does not occur.

In 2017, EPAGRI launched the 'Zafira' plum cultivar, the first plum cultivar for commercial purposes that is not naturally infected with $X$. fastidiosa, selected from the 'SC7' ('Leticia' $x$ 'Piamontesa') $x$ 'Fortune' cross performed in 2007 at the Experimental Station of Videira, SC. 'Piamontesa' is a resistant variety originally from Argentina. 'Letícia' and 'Fortune' are the most planted cultivars in southern Brazil. 'Zafira' plants have been kept free from $X$. fastidiosa for over ten years, without infection symptoms, in addition to showing negative results in Xylella PCR tests (DALBÓ et al., 2016; DALBÓ et al., 2018).

However, it was observed that the transmission of the bacteria occurs by grafting in the 'Zafira' cultivar. Apparently, this cultivar presents a mechanism that blocks transmission by insect vectors (leafhoppers) due to the effect of non-preference for food (DALBÓ et al., 2016). Its great advantage is the possibility of cultivation without the incidence of leaf scald. For this, it is necessary to avoid any type of over-grafting with susceptible materials, which allows the entry of bacteria through the connection of xylem vessels (DALBÓ et al., 2018).

The development of apparently uninfected plum genotypes under field conditions has opened new perspectives for disease control based on host plant resistance (DALBÓ et al., 2016; DALBÓ et al., 2018). EPAGRI results have shown that resistant genotypes affect the selection of host plants by leafhoppers and highlighted the importance of incorporating vector behavior into studies aimed at identifying or developing genotypes resistant to $X$. fastidiosa (KLEINA et al., 2020).

The Institute of Rural Development of Paraná IAPAR-EMATER (IDR-Paraná) evaluated different plum crosses and concluded that the 'PR-1095' genotype was the most resistant and did not show any foliar symptoms of the disease. However, the PCR test revealed the presence of the bacteria, indicating that the genotype is probably tolerant to leaf burning, in contrast, 'Piamontesa', 'PR 1142', 'PR 1149' and 'PR 1260' genotypes do not show symptoms in the field or presence of bacteria by PCR, showing resistance to the disease (GABARDO et al., 2020), but these new genotypes have not yet been launched.

Agrios (2005) defines tolerance as the ability of plants to produce good harvest, even when infected by a pathogen. Thus, these genotypes can be indicated even for regions with endemic presence of the pathogen. Resistant cultivars suppress, delay or prevent the entry or subsequent activity of the pathogen (growth and development) in their tissues (SHANKAR et al., 2020).
According to Nion and Toyota (2015), the use of resistant cultivars is a simple and efficient alternative for controlling diseases caused by bacteria. Resistant plants contribute to reduce the advance of PLS, not being a source of inoculum for susceptible varieties. It is noteworthy that sources of resistance or tolerance are of great value for disease control in the field.

\section{Concluding remarks}

Plum cultivation has great expansion potential in Brazil because the national production is not sufficient to meet the demand of the domestic market, being a good market niche to be explored. However, there is a need to develop management techniques and PLS resistant cultivars in the genetic improvement area in Brazil.

There are only few studies on disease management and control. Brazilian programs for the genetic improvement of plum trees have launched few cultivars resistant to the disease. There is a need for further studies aimed at launching new cultivars.

The use of certified propagation material, free from bacteria and the elimination of infected plants are the main measures currently used in Brazil. The vast majority of commercial cultivars are highly susceptible to the bacteria and only few cultivars of interest have any resistance.

In addition, the importance of disseminating knowledge about the disease to rural producers should be emphasized, collaborating to identify the initial symptoms and eradicate contaminated plants from orchards, as well as the use of management techniques that reduce the incidence of the disease.

\section{References}

AGRIOS, G.N. Plant pathology. $5^{\text {th }}$ ed. Amsterdam: Elsevier Academic Press, 2005.

ALMEIDA, R.P.P.; NUNNEY, L. How do plant diseases caused by Xylella fastidiosa emerge? Plant Disease, Saint Paul, v.99, n.11, p.1457-1467, 2015.

ALVES, E. Xylella fastidiosa - Adesão e colonização em vasos do xilema de laranjeira doce, cafeeiro, ameixeira, fumo e espécies de cigarrinhas vetoras e formação de biofilme sobre película de poliestireno. 2003. Tese (Doutorado em Agronomia) - Escola Superior de Agricultura "Luiz de Queiroz" - Universidade de São Paulo, Piracicaba, 2003.

AZEVEDO FILHO, W.S.; PALADINI, A.; BOTTON, M.; CARVALHO, G.S.; RINGENBERG, R.; LOPES, J.R.S. Manual de identificação de cigarrinhas em videira. Brasília (DF): Embrapa Informação Tecnológica, 2011. 95p. 
CASTRO, L.A.S. Protocolo para diagnóstico de escaldadura das folhas da ameixeira. Pelotas: Embrapa Clima Temperado, 2010. (Documentos, 324)

CATI-DSMM. A CATI no combate à escaldadura das folhas na ameixeira. 2009. (Artigo em Hypertexto). Disponível em: http://www.infobibos.com/ Artigos/2009_4/ameixa/index.htm. Acesso em: 09 jan. 2020.

CHATTERJEE, S.; ALMEIDA, R.P.Y LINDOW S. Living in two worlds: the plant and insect lifestyles of Xylella fastidiosa. Annual Review of Phytopathology, Palo Alto, v.46, p.243-271, 2008.

COLETTA-FILHO, H.; FRANCISCO, C.S.; LOPES, J.R.S.; DE OLIVEIRA, A.F.Y DA SILVA, L.F.O. First report of olive leaf scorch in Brazil, associated with Xylella fastidiosa subsp. Pauca. Phytopathology Mediterranean, Union, v.55, p.130-135, 2016.

DALBÓ, M.A., BRUNA, E.D., NODARI, R.O.AND SAIFERT, L. Plum selections with total resistance to leaf scald (Xylella fastidiosa). Acta Horticulturae, Leuven, n.1127, p.61-64, 2016.

DALBÓ, M.A.; BRUNA, E.D.; SOUZA, A.L.K. SCS 438 Zafira - a new plum cultivar resistant to leaf scald (Xylella fastidiosa). Crop Breeding and Applied Biotechnology, Viçosa, v.18, n.2, p.229-233, 2018.

DUCROQUET, J-P.H.J.; ANDRADE, E.R.; HICKEL, E.R. A escaldadura das folhas da ameixeira em Santa Catarina. Santa Catarina: EPAGRIO, 2001. (Boletim Técnico, 118).

EIDAM, T.; PAVANELLO, A.P.; AYUB, R. Ameixeira no Brasil. Revista Brasileira de Fruticultura, Jaboticabal, v.34, n.1, p.12-20, 2012.

EMBRAPA. Ameixa: produção e qualidade crescem em São Paulo. 2017. Disponível em: https://www.canalrural. com.br/progra-mas/ameixa-producao-qualidade-crescemsao-paulo-69866/. Acesso em: 20 set. 2020.

FAO. FAOSTAT: production - crops. Roma, 2020. Disponível em: http://faostat.fao.org/site/567/ DesktopDefault.aspx?PageID=567\#ancor. Acesso em: 06 jul. 2020.
FRANCIS, M.; LIN, H.; CABRERA-LA ROSA, J.; DODDAPANENI, H.; CIVEROLO, E.L. Genome-based PCR primers for specific and sensitive detection and quantification of Xylella fastidiosa. European Journal of Plant Pathology, Dordrecht, v.115, n.2, p.203-213, 2006.

FREITA, G.J.H. Host range of Pierce's disease virus of grapes as determined by insect transmission. Phytopathology, Saint Paul, v.41, p.920-934, 1951.

GABARDO, G.; SILVA, C.M.DA; SILVA, H.L.DA: IAUCHROWITZ, I.M.; CARVALHO, F.C.; LEITE JUNIOR, R.P. Selection of plum genotypes for resistance to leaf scald. Summa Phytopathologica, Botucatu, v.46, n.4, p.305-307, 2020.

GODEFROID, M.; CRUAUD, A.; STREITO, J.C.; RASPLUS, J.Y.; ROSSI, J.P. Xylella fastidiosa: climate suitability of European continent. Scientific Reports, London, v.9, n.1, p.1-10, 2019.

GOULD, A.B.; LASHOMB, J.H. Bacterial leaf scorch of shade trees. Saint Paul: The American Phytopathological Society, 2005. 19 p. Disponível em: www.apsnet.org

HARPER, S.J.; WARD, L.I.; CLOVER, G.R.G. Development of LAMP and real-time PCR methods for the rapid detection of Xylella fastidiosa for quarantine and field applications. Phytopathology, Saint Paul, v.100, n.12, p.1282-1288, 2010.

HARRIS, K.F.Y;; MARAMOROSCH, K. (ed). Vectors of plant pathogens. New York: Academic Press, 2013.

HILL, B.L.;PURCEL, A.H. Multiplication and movement of Xylella fastidiosa within grapevine and four other plants. Phytopathology, Saint Paul, v.85, n.11, p.13681372, 1995.

HOPKINS, D.L.Y.; PURCELL, A.H. Xylella fastidiosa: cause of Pierce's disease of grapevine and other emergent diseases. Plant Disease, Saint Paul, v.86, p.1056-1066, 2002.

JANSE, J.D.; OBRADOVIC, A.Xylella fastidiosa: its biology, diagnosis, control and risks.Journal of Plant Pathology, Stanford, v.1, p.35-48, 2010.

KILLINY N.; ALMEIDA R.P.P. Xylella fastidiosa afimbrial adhesins mediate cell transmission to plants by leafhopper vectors. Applied and Environmental Microbiology, Washington, v.75, p.521-528, 2009. 
KLEINA, H.T.; KUDLAWIEC, K.; ESTEVES, M.B.; DALBÓ, M.A.; DE PAULA OLIVEIRA, T.; MALUTA, N.; MAY-DE-MIO, L.L. Settling and feeding behavior of sharpshooter vectors of Xylella fastidiosa on plum genotypes resistant to leaf scald disease. European Journal of Plant Pathology, Dordrecht, v.158, n.3, p.633-644, 2020.

KRUGNER, R.Y LEDBETTER, C.A. Rootstock effects on almond leaf scorch disease incidence and severity. Plant Disease, Saint Paul, v.100, p.1617-1621, 2016.

LEITE, R.M.V.B.C.; LEITE JUNIOR, R.P.; CERESINI, P.C. Hospedeiros alternativos de Xylella fastidiosa entre plantas invasoras de pomares de ameixeira com escaldadura da folha. Fitopatologia Brasileira, Brasília, DF, v.22, n.1, p.54-57, 1997.

LI, Y.; HAO, G.; GALVANI, C.D.; MENG, Y.; DE LA FUENTE, L.; HOCH, H.C.Y BURR, T.J. Type I and type II pili of Xylella fastidiosa affect twitching motility, biofilm formation, and cell-wall aggregation. Microbiology, London, v.153, p.719-726, 2007.

MADAIL, J.C.M.; BELARMINO, L.C.; NEUTZLING, D.M. Custo de produção da ameixa, um caso da Serra Gaúcha. Pelotas: Embrapa Clima Temperado, 2007. (Comunicado Técnico, 157)

MAY DE MIO, L.L.; GARRIDO, L.da R.; UENO, B. Doenças de fruteiras de caroço. In: MONTEIRO, L.B.; MAY DE MIO, L.L.; SERRAT, B.M.; MOTTA, A.C.V.; CUQUEL, F.L. (ed.). Fruteiras de caroço: uma visão ecológica. Curitiba: UFPR, 2004. p.169-221.

MILANEZ, J.M.; PARRA, J.R.P.; CUSTÓDIO, I.A.; MAGRI, D.C.; CERA, C. Biology and thermal requirements of three leafhoppers vectors of bacterium Xylella fastidiosa. Citrus Research \& Technology, Campinas, v.23, n.1, p.127-140, 2017.

MIRANDA, M.P.DE; VIOLA, D.N.; MARQUES, R.N.; BONANI, J.P.; LOPES, J.R.S. Locais e período de alimentação da cigarrinha vetora de Xylella fastidiosa, Bucephalogonia xanthophis (Berg) (Hemiptera: Cicadellidae), em mudas cítricas. Revista Brasileira de Fruticultura, Jaboticabal, v.30, n.4, p.913-918, 2008.

MÜlleR, C.; ESTEVES, M.B.; KLEINA, H.T.; NONDILLO, A.; BOTTON, M.; LOPES, J.R.S. First sharpshooter species proven as vectors of Xylella fastidiosa subsp.multiplex in Prunus salicina trees in Brazil. Tropical Plant Pathology, Brasília, DF, v.1, p.16,2021 .
NION, Y.A.\& TOYOTA, K. Recent trends in control methods for bacterial wilt diseases caused by Ralstonia solanacearum. Microbes and environments, Taiwan, ME14144, 2015.

O'LEARY, M.L.; BURBANK, L.P.; KRUGNER, R.; STENGER, D.C. Complete genome sequence data of three Xylella fastidiosa subsp. multiplex strains isolated from olive trees in California, USA. Phytopathology, Saint Paul, v.110, n.11, p.1759-1762, 2020.

PALACIO BIELSA, A. Xylella fastidiosa, un problema global: enfermedades que causa, diagnóstico y control. Zaragosa: Editora Cita, 2017.

PEREIRA, É.F.; LOPES, J.R.S.; TURATI, D.T.; MUNHOZ, C.; CORRENTE, J.E. Influência das condições hídricas do solo e da temperatura na sobrevivência e alimentação de Oncometopia facialis (Hemiptera: cicadellidae) em "seedlings" de citros. Arquivos do Instituto Biológico, São Paulo, v.72, p.343-351, 2005.

PURCELL, A.H. Leafhopper vectors of xylem-borne plant pathogens. In: HARRIS, K.F.; MARAMOROSCH, $\mathrm{K}$. Leafhopper vectors and plant disease agents. New York: Academic Press, 1979. p.615-625.

REDAK, R.A.; PURCELL, A.H.; LOPES, J.R.S.; BLUA, M.J.; MIZEL III, R.F.Y ANDERSEN, P.C. The biology of xylem fluid-feeding insect vectors of Xylella fastidiosa and their relation to disease epidemiology. Annual Review of Entomology, Palo Alto, v.49, p.243-270, 2004.

RETCHLESS, A.C.; LABROUSSAA, F.; SHAPIRO, L.; STENGER, D.C.; LINDOW, S.E.Y ALMEIDA, R.P.P. Genomic insights into Xylella fastidiosa interactions with plant and insect hosts. In: GROSS, D.C.; LICHENSPARK, A.Y.; KOLE, C. (ed.). Genomics of plantassociated bacteria. Berlin: Springer, 2014. p.177-202.

ROPER, M.C.; GREVE, L.C.; WARREN, J.G.; LABAVITCH, J.M.Y KIRKPATRICK, B.C. Xylella fastidiosa requires polygalacturonase for colonization and pathogenicity in Vitis vinifera grapevines. Molecular Plant-Microbe Interactions, London, v.20, p.411-419, 2007.

SADDLER, G.S.Y BRADBURY, J.F. Xylella. In: Bergey's manual of systematics of archaea and bacteria. New Jersey: Wiley, 2015. p.1-10. 
SAFADY, N.G.; LOPES, J.R.S.; FRANCISCO, C.S.; DELLA COLETTA-FILHO, H. Distribution and genetic diversity of Xylella fastidiosa subsp.pauca associated with olive quick syndrome symptoms in Southeastern Brazil. Phytopathology, Saint Paul, v.109, n.2, p.257264, 2019.

SANDERLIN, R.S.Y MELANSON, R.A. Reduction of Xylella fastidiosa transmission through pecan scion wood by hot-water treatment. Plant Disease, Saint Paul, v.92, p.1124-1126, 2008.

SCHAAD, N.W.; POSTNIKOVA, E.; LACY, G.; FATMI, M.B.; CHANG, C.J. Xylella fastidiosa subspecies: X.fastidiosa subsp. piercei, subsp.nov., X.fastidiosa subsp. multiplex subsp. nov., and $X$. fastidiosa subsp. pauca subsp.nov. Systematic and Applied Microbiology, Marlborough House, v.27, p.290-300, 2004.

SCHNEIDER, N.A.; DE AZEVEDO FILHO, W.S. Epidemiologia da escaldadura das folhas da ameixeira. Caderno de Pesquisa, Santa Cruz do Sul, v.26, n.2, p.25-40, 2014.

SEAB/DERAL- Secretaria da Agricultura e do Abastecimento, Departamento de Economia Rural. Disponível em: http://www.agricultura.pr.gov.br/arquivos/ File/deral/Prognosticos/2017/Fruticultura_2016_17.pdf. Acesso em: 29 de jan.2018.
SHANKAR, M.; REEVES, K.; BRADLEY, J.; VARISCHETTI, R.; LOUGHMAN, R. Effect of varietal resistance on the yield loss function of wheat to nodorum blotch. Plant Pathology, London, v.1, p.1-15, 2020.

SICARD, A.; ZEILINGER, A.R.; VANHOVE, M.; SCHARTEL, T.E.; BEAL, D.J.; DAUGHERTY, M.P.; ALMEIDA, R.P. Xylella fastidiosa: insights into an emerging plant pathogen. Annual review of phytopathology, Palo Alto, v.56, p.181-202, 2018.

WELLS, J.M.; RAJU, B.C.; HUNG, H-Y.; WEISBURG, W.G.; MANDELCO- PAUL, L.; BRENNER D.J. Xylella fastidiosa gen.nov., sp.nov: Gram-negative, xylemlimited, fastidious plant bacteria related to Xanthomonas spp. International Journal of Systematic Bacteriology, Washington, v.37, n.2, p.136-143, 1987.

YAMAMOTO, P.T.; ROBERTO, S.R.; DALLA PRIA JUNIOR, W. Inseticidas sistêmicos aplicados via tronco para controle de Oncometopia facialis, Phyllocnistis citrella e Toxoptera citricida em citros. Scientia Agricola, Piracicaba, v.57, n.3, p.415-420, 2000.

YONCE, C.E.; SHANG, C.J. Detection of Xylella-limited bacteria from sharpshooter leafhoppers and their feeding hosts in peach environs monitored by culture isolations and ELISA techniques. Environmental Entomology, Lanham, v.16, p.68-71, 1987. 